\title{
Demand-side management possibilities in sustainable energy systems: A case study in the Bükkalja region, Hungary
}

\begin{abstract}
Transition from fossil and nuclear fuels to renewable energy sources is a fundamental aspect of global and community level projects for sustainable development. The hypothesis of this study is that energy efficiency measures have significant potential to reduce the consumption of highly polluting fuels supplying the energy needs of the residential sector. The increasing use of renewable energy resources requires technical and economic changes in the energy sector to ensure a proper balance between supply and demand. Demand-side management methods consider various technologies, flexible price mechanisms, and human behaviour patterns to plan and implement policies intended to reduce and/or shift energy consumption to increase energy system flexibility and societal benefits. The research focuses on the residential sector in Hungary. With the Long-range Energy Alternative Planning (LEAP) software, a multidisciplinary analysis was conducted and four energy scenarios were designed in order to assess energy savings and responsive demand potential. The results demonstrated that approximately $70 \%$ of the final energy consumption for heat in the sector can be reduced. Up to $2981 \mathrm{MWh} /$ year of the total electricity consumption of the research area can be utilised for strategic management with the proposed household retrofits.
\end{abstract}

Keywords: demand-side management, energy planning, LEAP, renewable energy

1 Eötvös Loránd University; e-mail: zeca@caesar.elte.hu.

DOI: http://dx.doi.org/10.31570/Prosp 2019032.

The research work was carried out in the frame of the Sustainable Energy Planning Research Group at the Department of Environmental and Landscape Geography of the Institute of Geography and Earth Sciences of ELTE TTK. The author would like to express his gratitude to Professor Béla Munkácsy and PhD students Csaba Csontos and Tamás Soha for advising in all aspects of this paper, and all the students who were involved in the surveying. 


\section{Introduction and theoretical background}

In the transition to a low-carbon energy system, it is not only crucial to replace fossil fuels and nuclear power, but also to reduce the overall energy consumption. Energy efficiency measures have the potential to substantially contribute to the reduction of primary energy demand (Kemp 2010). The expected transition to renewable energy sources in the near future implies significant expansion of decentralised generation, mainly utilising small scale systems (Munkácsy-Kadar 2016) significant focus is put on the electricity sector alone to solve the renewable energy integration puzzle. Smart grid research traditionally focuses on ICT, smart meters, electricity storage technologies, and local (electric) smart grids. The use of renewable sources, however, makes the balance of supply and demand of power much more complex due to weather fluctuations (Gellings 2009). In the residential sector, the use of renewable sources for heat and electricity generation is part of the solution, but adequate thermal insulation and efficient power consuming appliances are indispensable to decarbonise the energy system (Lund et al. 2014).

Electricity is consumed with different intensity and at different periods of the day based on the consumers' needs. In fact, throughout the day, the demand goes up and down, resulting in peak and off-peak hours of consumption in the so-called electrical load curve (Gellings 2009). Demand-side management (DSM) programmes are based on the principle that with changes in the consumers demand profile, financial and environmental benefits can be achieved (Wenstedt et al. 2007). Several DSM methods are used to better manage the energy system (Gellings 2009), but a common goal can be highlighted: achieving the reduction of electricity consumption or shift demand from peak to off-peak hours. These opportunities can be identified through comprehensive load research. By reducing the overall consumption, DSM programmes reduce the need for power plants used to specifically attend peak load, which typically run on fossil fuels, thus contributing to a cleaner environment (Papaefthymiou 2012). Moreover, with the development of Information and Communication Technologies (ICT) and smart grids, the sectorial approach to the energy system has been shifted to an integrated one where the focus is not only on the electricity, but also on the heat and transport infrastructure as a whole (Mathiesen et al. 2015).

In order to implement DSM programmes at different levels of society, financing programmes to assist consumers to pay for improvements are needed as well as schemes and incentives to invest in energy conservation and efficiency (Mukhopadhyay-Rajput 2010). 
In Hungary, $40 \%$ of total energy is currently consumed in buildings, about two thirds of which goes for heating and cooling, where natural gas is responsible for almost $70 \%$ of the share of heat generation (IEA 2017). One of the main reasons behind this impressive figure is that $70 \%$ of Hungarian homes fail to meet thermal insulation requirements (Ministry of National Development 2012: 33).

\section{Methodology}

The research focuses on the residential sector, which is one of the subsectors of the building sector, and investigates the hypothesis that energy-efficient technologies have significant potential to reduce consumption related to space and water heating. The research area comprehends 6006 households in Northern Hungary. The main data source is a field survey of the Bükkalja region. This survey was crucial to acquire information on building stock characteristics, heat demand profile, technologies used for energy transformation (e. g. boiler, stove, wood-fired boiler) and fuels utilised. The 14 settlements were visited by the research group between 2015 and 2018. The survey reached at least $10 \%$ of the total number of households in each settlement. Data were extrapolated within each settlement. Publications from the Hungarian Central Statistical Office (KSH) and Hungarian Energy and Public Utility Regulatory Authority (MEKH) were consulted as official sources. The following step in the research was the development of long-term energy scenarios characterised by energy efficiency measures and high penetration of renewable energy sources (Munkácsy 2011). One of the goals is to identify viable strategies for a sustainable and healthier low-carbon energy system where lignite and natural gas are gradually replaced by alternative sources for residential heating. A model was created to calculate the final $^{2}$ and useful ${ }^{3}$ energy use of the sector with the Long-range Energy Alternative Planning System (LEAP).

\section{Research area}

The research area is located in the Miskolc-Bükkalja region, in the southern slopes of the Bükk mountains, Hungary. In this region citizens of 42 settlements had the initiative to create a $\mathrm{LEADER}^{4}$ community focusing on sustainable energy solutions. Eleven

2 The term refers to the primary energy, electricity, and ambient heat before transformation.

3 The term refers to the delivered energy minus losses in the transformation.

4 LEADER is a European Union initiative to support rural development projects initiated at the local level in order to revitalise rural areas and create jobs. 
settlements investigated in this paper are part of the LEADER initiative (Bogács, Borsodgeszt, Bükkábrány, Bükkzsérc, Cserépfalu, Cserépváralja, Harsány, Kács, Szomolya, Tard, and Tibolddaróc) and three are not involved in the initiative (Csincse, Mezőnyárád, and Vatta). In the Bükkalja region, the project began eight years ago, however, the achievements have been limited due to several factors. It is important to notice that an existing environmental problem of the Miskolc-Bükkalja region is wintertime smog. Wet wood, locally mined lignite and illegal burning of household waste are used to produce heat, contributing to the air concentration of particulate matters (PM).

From the field survey, the average heated area in the households was assessed to be in the order of $88 \mathrm{~m}^{2}$ with a mean heat demand of $246.5 \mathrm{kWh} / \mathrm{m}^{2}$ per year.

The main fuels used for heat generation in the region are lignite, forest wood (with high moisture), and natural gas. A small portion of family houses in the area use a mix of all three fuels, however, forest wood and natural gas are used for space heating in most cases. The final primary energy consumption by fuel type is presented in Table 1 .

Table 1. Average annual primary energy consumption by fuel type in the study area

\begin{tabular}{lc}
\hline \multicolumn{1}{c}{ Fuel } & Energy consumption (MWh) \\
\hline Natural gas & 37707.0 \\
Lignite & 21722.3 \\
Wood & 152507.5 \\
\hline
\end{tabular}

\section{Key assumptions}

In the Bükkalja region, as a whole, the population is declining (KSH 2018); consequently, the number of inhabited households follows this trend. The field survey was the main source to assess the current household retrofit trend in the area. In summary, the scenarios take into consideration the following energy consumption trends as reference: population change, changes in the number of households, building characteristics (heated area and heat demand), and energy efficiency improvements. Four energy scenarios were designed considering these key assumptions for the period from 2020 to 2040 . 
In order to calculate the useful energy demand, the following calorific values were assumed for the fuels consumed in the area: $2.44 \mathrm{kWh} / \mathrm{kg}$ of lignite, $2.42 \mathrm{kWh} / \mathrm{kg}$ of wood and $34.73 \mathrm{MJ} / \mathrm{m}^{3}$ of natural gas (FGSZ 2019; Krajnc 2015; MERT 2019).

As for energy savings, buildings are often partially improved (e. g. replacement of windows and entrance door, façade wall, attic roof) and the quality of the work varies, resulting in different levels of energy savings, as reported for the Hungarian building stock by Csoknyai et al. (2016). Hermeling (2006) found that highly efficient improvements are also possible for typical existing Hungarian dwellings. Moreover, substantial energy savings can be achieved at low and negative costs as reported by Novikova (2008). Based on these studies, the present paper considers different levels of energy efficiency achievable with building retrofit. In terms of heat and energy storage, ground-source heat pump coupled with thermal storage (TES) systems is considered in the alternative scenarios to modernise the heating system. The coefficient of performance (ratio of useful heating provided) considered for the heat pump is 5.6 (Chua et al. 2010). The thermal storage capacity of $1 \mathrm{~m}^{3}$ is adopted for in order to promote electrical load flexibility (Arteconi et al. 2014).

\section{Scenarios}

Business-as-usual (BAU) is the reference case that considers the current renovation rate (as learned from the field survey) $0.5 \%$ of houses per year. The improvements result in $50 \%$ reduction in heat demand. Three alternative scenarios were created to explore the energy-saving possibilities. These were named Standard (SEE), Advanced (AEE) and Deep Energy Efficiency (DEE). For SEE, energy savings in the order of $50 \%$ are considered with a renovation rate of $1.25 \%$ per year, while AEE considers more efficient initiatives that achieve heat demand reduction in the order of 70\% (Csoknyai et al. 2016 ) with a renovation rate of $2.5 \%$ per year. Finally, DEE considers $90 \%$ reduction in the heat demand (Hermelink 2006) with a renovation rate of $3.75 \%$ per year.

\section{Results and discussion}

The expected demand for the period between 2020 and 2040 was projected. The energy demand is expected to shrink by $11 \%$ due to population movement from the countryside to cities. In order to meet this demand, the fuels currently used are considered in the BAU scenario, while a low-carbon option is introduced with different rates in the three alternative scenarios. A reduction of $17.6 \%$ in the total energy demand is observed 
when SEE scenario is compared to BAU by the end of the study period. If scenario AEE and DEE are compared to BAU, the reduction is $41.1 \%$ and $70.5 \%$, respectively.

The share of fuels in terms of useful energy was investigated for scenarios SEE, AEE, and DEE. This calculation considers the efficiency of technologies used for transformation. When considering the AEE scenario, the useful energy required to meet the demand in 2040 is lower by $35.04 \%$. This scenario was chosen for further discussion since it is an intermediate option between SEE and the more optimistic DEE scenario.

Figure 1. a) Total primary energy, electricity and ambient heat in the four scenarios

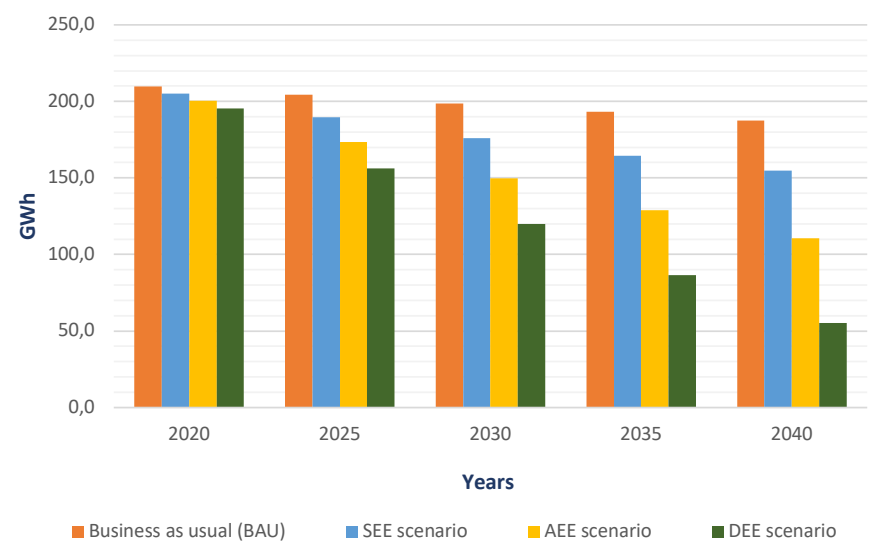

b) The share of fuels in terms of useful energy in scenario AEE

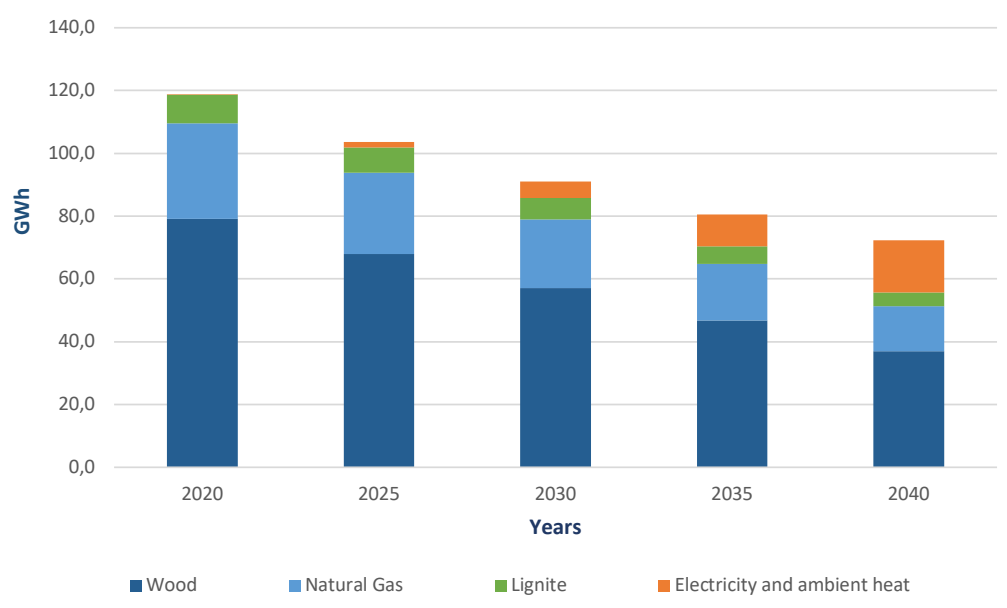


The responsive load refers to the potential flexible electricity load attributed to the operation of heat pumps with TES unit. These DSM strategies aim to make the electricity demand follow the energy production in a dynamic manner. The operation of heat pumps (with TES units) in off-peak hours can reduce the electricity consumption during peak hours of electricity demand. In Hungary, this is the period between 16:00 and 19:00 hours during the winter (MEKH 2017). Final consumers are influenced to adopt the practice by preferential electricity tariffs and time-of-use tariffs. In the operation area of ELMÜ Hálózati Kft. (Hungary), consumers can adopt the so-called GEO tariff for cheaper electricity for heat pump operation or time-based pricing, such as the A2 tariff category (ELMÜ-ÉMÁSZ 2019).

Table 2. Prospective responsive electrical load in the research area (MWh)

\begin{tabular}{lccc}
\hline Scenario & Year 2020 & Year 2030 & Year 2040 \\
\hline SEE & 22.95 & 782.69 & 2484.16 \\
AEE & 27.54 & 939.22 & 2981 \\
\hline DEE & 13.77 & 469.61 & 1490.5 \\
\hline
\end{tabular}

\section{Conclusion}

With sustainable energy management strategies, $70.5 \%$ of final residential energy consumption for heating purposes can be saved, mainly by building stock renovation and improvements in thermal insulation. SEE, AEE, and DEE scenarios investigated the integration of the electricity and heating sectors via utilisation of renewable energy sources, namely, heat pumps combined TES systems. AEE was discussed in further details. In terms of electricity, up to $2981 \mathrm{MWh}$ /year of the area's total electricity demand can potentially be used for strategic management by 2040 if measures suggested in this scenario are adopted. The responsive demand quantitatively decreases in the DEE scenario due to broader energy saving measures in place. In terms of demand-side management, AEE was found to offer greater potential since the retrofit rate is higher than in SEE but the energy saving measures are not as effective as those proposed in DEE. 


\section{References}

Arteconi, A. - Polonara, F. - Brandoni, C. (2014). Demand side management of the built environment for sustainable energy. Energy Production and Management in the 21st Century. https://doi.org/10.2495/eq140682.

Chua, K. J. - Chou, S. K. - Yang, W. M. (2010). Advances in heat pump systems: A review. Applied Energy, (87)12, 3611-3624. https://doi.org/10.1016/j.apenergy.2010.06.014.

Csoknyai, T. - Hrabovszky-Horváth, S. - Georgiev, Z. - Jovanovic-Popovic, M. - Stankovic, B. - Villatoro, O. - Szendrö, G. (2016). Building stock characteristics and energy performance of residential buildings in Eastern-European countries. Energy and Buildings, 132, 39-52. https://doi.org/10.1016/j.enbuild.2016.06.062.

ELMÜ-ÉMÁSZ (2019). Electricity tariff (Villamosenergia-tarifák). Retrieved May 10, 2019; from https://elmuemasz.hu/egyetemes-szolgaltatas/szolgaltatasok/villamosenergia/villamos-energia-tarifak.

FGSZ (2019). Order of natural gas quality accounting. Retrieved May 10, 2019, from https://fgsz.hu/en/for-business/network-users/regulatory-framework/order-of-natural-gas-quality-accounting.

Gellings, C. W. (2009). The smart grid: Enabling energy efficiency and demand response. Lilburn, GA: Fairmont.

Hermelink, A. (2006). A retrofit for sustainability: Meeting occupants' needs within environmental limits. In Conference Proceedings, 14th ACEEE Summer Study on Energy Efficiency in Buildings, (13)18.

IEA (2017). Energy policies of IEA countries: Hungary, 2017 review. Paris: International Energy Agency.

Kemp, M. (2010). Zero carbon Britain 2030. Walles: Centre for Alternative Technology, 79.

Krajnc, N. (2015). Wood fuels handbook. Pristina: Food and Agricultural Organisation of the United Nations.

KSH (2018). STADAT Time series of annual data - Housing and public utilities. Budapest: Hungarian Central Statistical Office. Retrieved from http://www.ksh.hu/stadat annual 23.

Lund, H. - Werner, S. - Wiltshire, R. - Svendsen, S. - Thorsen, J. E. - Hvelplund, F. Mathiesen, B. V. (2014). 4th Generation District Heating (4GDH). Energy, 68, 1-11. https://doi.org/10.1016/j.energy.2014.02.089. 
Mathiesen, B.V. - Lund, H. - Connolly, D. - Wenzel, H. - Østergaard, P. A. - Möller, B. - Hvelplund, F. K. (2015). Smart Energy Systems for coherent 100\% renewable energy and transport solutions. Applied Energy, 145, 139-154. https://doi. org/10.1016/j.apenergy.2015.01.075.

MEKH (2017). Data of the Hungarian Electricity System 2017. Budapest: Hungarian Energy and Public Utility Regulatory Authority.

MERT (2019). Bükkábrányi szénértékesítés. Retrieved October 18, 2019; from http:// www.mert.hu/bukkebranyi-szenertekesites. Ministry of National Development (2012). National Energy Strategy 2030. Budapest: Ministry of National Development.

Munkácsy B. (2011). Erre van elöre! Egy fenntartható energiarendszer keretei Magyarországon: Vision 2040 Hungary 1.0. Szigetszentmiklós: Környezeti Nevelési Hálózat Országos Egyesület.

Munkácsy, B. - Kadar, P. (2016). Seeking the sustainable power mix for Central Europe. 2016 IEEE 14th International Symposium on Intelligent Systems and Informatics (SISY). https://doi.org/10.1109/sisy.2016.7601508.

Mukhopadhyay, S. - Rajput, A. K. (2010). Demand side management and load control: An Indian experience. IEEE PES General Meeting. https://doi.org/10.1109/ pes.2010.5589589.

Novikova, A. (2008). Carbon dioxide mitigation potential in the Hungarian residential sector (Doctoral dissertation). Retrieved March 10, 2019, from https://envsci.ceu. edu/sites/ envsci.ceu.hu / files/ attachment/ project/ 517/aleksandranovikovadissertation.pdf.

Papaefthymiou, G. - Hasche, B. - Nabe, C. (2012). Potential of heat pumps for demand side management and wind power integration in the German electricity market. IEEE Transactions on Sustainable Energy, (3)4, 636-642. https://doi.org/10.1109/ tste.2012.2202132.

Wernstedt, F. - Davidsson, P. - Johansson, C. (2007). Demand side management in district heating systems. Proceedings of the 6th International Joint Conference on Autonomous Agents and Multiagent Systems - AAMAS '07. https://doi.org/ $\underline{10.1145 / 1329125.1329454 .}$. 